\title{
Effects of different protein sources on fermentation metabolites and nutrient digestibility of brachycephalic dogs
}

\author{
Maria Isabel Gonzalez Urrego ${ }^{1}$, Laura Fantucci de O. Matheus ${ }^{2}$, Karine de Melo Santos ${ }^{2}$, \\ Mariane Ceschin Ernandes ${ }^{2}$, Mariana Monti ${ }^{3}$, Danilo Ferreira de Souza ${ }^{3}$, Júlio Cesar de Carvalho Balieiro ${ }^{2}$, \\ Lúcio Francelino Araújo ${ }^{1}$, Cristiana F. Ferreira Pontieri ${ }^{3}$ and Márcio Antonio Brunetto ${ }^{2} *$ \\ ${ }^{1}$ Faculty of Animal Science and Food Engineering (FZEA), University of São Paulo (USP), Pirassununga, São Paulo, Brazil \\ ${ }^{2}$ School of Veterinary Medicine and Animal Science (FMVZ), University of São Paulo (USP), Pirassununga, São Paulo, Brazil \\ ${ }^{3}$ Grandfood Indústria e Comércio LTDA, Dourado, São Paulo, Brazil
}

(Received 14 November 2016 - Final revision received 6 July 2017 - Accepted 10 July 2017)

Journal of Nutritional Science (2017), vol. 6, e43, page 1 of 5

doi:10.1017/jns.2017.46

\section{Abstract}

Benefits to microbial fermentation in the colon and as a consequence less flatulence can be promoted for the health of adult dogs according to the amount and protein source. The present study evaluated different protein sources in dry food for brachycephalic dogs regarding microbial fermentation and nutrient digestibility. Four dry dog foods with similar protein content were formulated for adult maintenance: poultry meal (PM) diet; wheat gluten (WG) diet; PM + WG diet; and PM + WG + hydrolysed protein (HP) diet. Eight French bulldog adult dogs were arranged in a $4 \times 4$ Latin square design during the $28 \mathrm{~d}$ trial. Fresh faeces were collected for assessment of nutrient digestibility and analyses of faecal $\mathrm{pH}$, SCFA, biogenic amines, ammonia and lactate. Means were compared by the PROC MIXED procedure of SAS and by Tukey's test, considering $P \leq 0 \cdot 05$. The animals fed the WG and PM + WG diets showed higher digestibility for DM $(P<0 \cdot 05)$, organic matter $(P<0 \cdot 05)$, crude protein $(P<0.001)$ and lower faeces production $(P<0 \cdot 02)$ than the PM and PM + $\mathrm{WG}+\mathrm{HP}$ diets. Feeding diet $\mathrm{PM}+\mathrm{WG}+\mathrm{HP}$ resulted in lower faecal score and $\mathrm{pH}(P<0 \cdot 05)$ compared with other diets. Concentrations of fermentation metabolites were not statistically significantly different among diets. In conclusion, WG alone or in combination with PM improved protein and DM digestibility. Fermentation products were not affected by protein source.

Key words: Brachycephalic dogs: Protein fermentation: Wheat gluten: Protein

Several factors may influence the amount of protein that reaches the colon after feeding, such as the amount of DM ingested and content and digestibility of protein sources included in the diet. Therefore, the use of highly digestible protein sources results in less flow of protein residues in the large intestine and a possible reduction in production of fermentation metabolites and flatulence in $\operatorname{dogs}{ }^{(1,2)}$.

Although digestion and absorption of proteins in the small intestine are efficient processes, substantial amounts of undigested proteins are directed to the large intestine ${ }^{(3,4)}$, where the microbial fermentation of these components results in the production of various putrefaction compounds, such as ammonia, phenols, indoles, SCFA, branched-chain fatty acids, gases $\left(\mathrm{H}_{2}, \mathrm{CO}_{2}\right.$ and methane), biogenic amines (putrescine, cadaverine, histamine, phenylethylamine) and lactate. Some of these compounds influence faecal odour and can be toxic if produced in high concentrations ${ }^{(5,6)}$. Moreover, according to Zentek et al. ${ }^{(7)}$, the ingestion of diets with high concentrations of proteins favours the growth of undesirable bacteria, such as Clostridium perfringens, and decreases the faecal counts

Abbreviations: CTTAD, coefficient of total tract apparent digestibility; HP, hydrolysed protein; PM, poultry meal; WG, wheat gluten.

* Corresponding author: M. A. Brunetto, fax +55 0193565 4041, email mabrunetto@usp.br 
of other beneficial bacteria, resulting in imbalance in the intestinal microbiota and consequent increase in excretion of enterotoxins and other metabolic products related to the increase of the protein decomposition in the colon.

Brachycephalic dog breeds such as French bulldogs have been identified as having faeces with a stronger odour and higher frequency of flatulence. Their typical anatomical characteristics result in aerophagia, predisposing to increased gas production. This gas production is associated with a higher presence of non-assimilated substrates, resulting in flatulence and foul-smelling faeces ${ }^{(8,9)}$. Degradation of undigested proteins in the colon may be responsible for the strong faecal odour in brachycephalic dogs. Therefore, nutritional strategies based on sources and altered concentrations of protein may be important in reducing the impact of fermentative activity in the colon and thus modulate the composition of the intestinal microbiota. Its metabolic activity and the formation of fermentation products are effects that can be important for the reduction of strong faecal odour in brachycephalic dogs. Zentek ${ }^{(10)}$ reported that dogs fed with higher digestible proteins had lower amounts of protein in the ileal chyme which would allow the decrease in putrefaction in the posterior intestine, and consequently reduction of the compounds involved in the gases and bad faecal odour. Thus, the improvement of protein quality and the use of different protein sources in dog food will decrease the fermentation products and as a consequence the odour of faeces in dogs of the French bulldog breed.

The objective of the present study was to evaluate the effects of inclusion of various protein sources in dry dog diets on the digestibility of nutrients and faecal fermentation products in adult brachycephalic dogs.

\section{Material and methods}

The present study was conducted at the Nutrition Development Center of PremieR Pet, Dourado, São Paulo, Brazil, jointly with the Department of Animal Production and Nutrition at the School of Veterinary Medicine and Animal Science of the University of São Paulo, Pirassununga, São Paulo, Brazil. All care procedures were approved by the Ethics Research Committee on Animal Use of PremieR Pet (CEUA PremieR Pet - protocol no. 028-14).

\section{Animals, facilities and experimental design}

Eight healthy adult French bulldog dogs (one male and seven female), intact and neutered, mean weight of 11.09 (SD 2.35) kg, mean age of 2.75 (SD 1.98) years and body condition score between 4 and 5 (9-point body condition score by Laflamme ${ }^{(11)}$ ) were used. Health status was confirmed before the beginning of the experiment by physical, blood and coproparasitological examinations. Dogs were previously dewormed and were up to date with vaccinations. The dogs were housed individually in kennels with solarium $\left(11.2 \mathrm{~m}^{2}\right)$. The animals were distributed in replicate $4 \times 4$ Latin squares, four treatments (diets) and four periods, totalling eight replicates per treatment. The treatments were balanced by the animals' body weight.
Each experimental period lasted $28 \mathrm{~d}$. The animals were adapted to the diet for $20 \mathrm{~d}$; followed by $5 \mathrm{~d}$ of faecal collection for apparent digestibility and faecal score; and $3 \mathrm{~d}$ of fresh faeces collection to determine the fermentation products.

\section{Diets}

Four extruded isonutrient diets were produced to meet the adequate intake of the requirements for the maintenance of adult $\operatorname{dog} \mathrm{s}^{(12)}$, containing: brewer's rice, beet pulp, cellulose, chicken fat, fish oil, egg powder, brewer's yeast, palatability enhancer, potassium chloride, mineral-vitamin premix, magnesium oxide, salt, dicalcium phosphate, calcium carbonate and antioxidant. The diets presented contained $13 \%$ of protein from different sources (poultry meal (PM); wheat gluten (WG); PM + WG (50\% PM and $50 \% \mathrm{WG}) ; \mathrm{PM}+\mathrm{WG}+$ liver hydrolysed protein (HP) (PM, WG and HP, with $33.33 \%$ inclusion of each)). The diets' proximate analyses composition means were approximately: $23 \%$ protein, $16 \%$ fat, $3 \%$ crude fibre, $6 \%$ ash, $7 \%$ moisture, $54 \% \mathrm{~N}$-free extract and $3.9 \mathrm{kcal} / \mathrm{kg}(16.3 \mathrm{~kJ} / \mathrm{kg})$. To verify if the extrusion processing conditions were able to cook the starch, the degree of gelatinisation of the starch was determined by the amyloglucosidase method described by Sá et al. ${ }^{(13)}$

\section{Food intake and digestibility experiment}

The total faecal collection method was used to perform the coefficients of total tract apparent digestibility (CTTAD) assay ${ }^{(14)}$, consisting of an initial phase of $20 \mathrm{~d}$ of adaptation to the diet, followed by $5 \mathrm{~d}$ of faecal collection. The animals were fed twice per $\mathrm{d}(07.00$ and 16.30 hours) and received water ad libitum. The amount of food offered and refused was recorded at each meal. The amount of food offered was calculated by formula: $130 \times$ body weight $^{0.75}=\mathrm{kcal} / \mathrm{d}\left(544 \times\right.$ body weight $\left.^{0.75}=\mathrm{kJ} / \mathrm{d}\right)$, based on the energy requirement prediction equation for maintenance of active adult $\operatorname{dogs}{ }^{(12)}$. The food offered was weekly adjusted to keep the animals' body weight stable.

The faeces were individually collected, weighed and kept in a freezer $\left(-20^{\circ} \mathrm{C}\right)$ for further analysis. After the collection period, the faecal samples were thawed, homogenised, and pooled for each animal and period. Faecal samples were dried in a forced-air oven (320SE; Fanem) at $55^{\circ} \mathrm{C}$ for $72 \mathrm{~h}$. Dried faeces and feed samples were then ground in a cutting mill with a $1 \mathrm{~mm}$ screen sieve (MOD 340; ART LAB). The qualitative analysis of the faeces was determined over the stool collection period for digestibility, scoring from 1 (watery stools) to 5 (very hard and resected stools) $^{(15)}$. Based on laboratory results, the CT'TAD of DM, crude protein, ether extract in acid hydrolysis, organic matter, $\mathrm{N}$-free extract and gross energy were calculated according to the equation of Pond et al. ${ }^{(16)}$

Diets and faeces were submitted to DM, crude protein, ether extract in acid hydrolysis, crude fibre and ash analyses according to the Association of Official Analytical Chemists $(\mathrm{AOAC})^{(17)}$. Gross energy was determined in a bomb calorimeter (1281; Parr Instrument Company). All analyses were conducted in duplicate and were repeated when $\mathrm{CV}$ was greater than $5 \%$. 


\section{Fermentation metabolites}

Fresh faeces were collected up to $30 \mathrm{~min}$ after defecation. Faecal $\mathrm{pH}$ was determined by digital $\mathrm{pH}$ meter (DM-20; Digimed) in a solution of faeces and distilled water $(2 \mathrm{~g} / 18 \mathrm{ml})^{(18)}$. Lactic acid concentration was measured by spectrophotometry at $565 \mathrm{~nm}$ (QUICK-Lab; DRAKE Eletrônica Comércio LTDA) ${ }^{(19)}$. Faeces were diluted in distilled water $(3 \mathrm{~g} / 9 \mathrm{ml})$.

For SCFA and branched-chain fatty acid determinations, $3 \mathrm{~g}$ faeces were diluted in $9 \mathrm{ml}$ of $16 \%$ formic acid, kept in a refrigerator, homogenised daily and centrifuged for $15 \mathrm{~min}$ at $15^{\circ} \mathrm{C}$ and $5000 \mathrm{rpm}$. This procedure was repeated three times using only the supernatant fraction and stored in a freezer $\left(-15^{\circ} \mathrm{C}\right)$. SCFA and branched-chain fatty acids were determined by GC, according to methodology described in the literature ${ }^{(20)}$.

The biogenic amine profile was determined using $0.5 \mathrm{~g}$ faeces preserved in $7 \mathrm{ml}$ of $5 \%$ trichloroacetic acid. The samples were then centrifuged and filtered according to Vale \& Gloria $^{(21)}$. Identification of the amines was performed by HPLC (Shimadzu Corporation).

Ammonia concentration was determined using $3 \mathrm{~g}$ faeces acidified with $9 \mathrm{ml}$ of $16 \%$ formic acid. The samples were centrifuged and stored according to the methodology described for SCFA determination. Aliquots of $2 \mathrm{ml}$ were diluted in $13 \mathrm{ml}$ distilled water and distilled in $\mathrm{N}$ distillation. The distillation was carried out with $5 \mathrm{ml}$ of $2 \mathrm{M}$-potassium hydroxide solution and the titration with hydrochloric acid $(0 \cdot 005 \mathrm{~mol} / \mathrm{l})^{(22)}$.

\section{Statistical analysis}

The data were analysed considering a duplicate $4 \times 4$ Latin square design. Treatments were compared by ANOVA and, in case of significant effects, we used Tukey's test for post hoc group comparisons. The analyses were performed by PROC MIXED, using version 9.3 of SAS software ${ }^{(23)}$. The model contemplated the treatment as fixed effect, and the animal and the period as random effects. Statistical significance was set at $P<0 \cdot 05$.

\section{Results}

The body weight of the animals did not change during the study. Food intake did not differ between diets $(P>0 \cdot 05$; Table 1). The PM, WG, PM + WG and PM+WG + HP diets presented, respectively, 91.0, 87.4, 98.5 and 77.7 \% gelatinisation of starch. Animals fed the PM + WG diet had a greater CTTAD for DM $(P<0.05)$ and those fed the WG diet for organic matter $(P<0 \cdot 05)$. A higher CTTAD for crude protein was observed for the WG and $\mathrm{PM}+\mathrm{WG}$ diets compared with the PM and $\mathrm{PM}+\mathrm{WG}+\mathrm{HP}$ diets. Feeding the $\mathrm{PM}+\mathrm{WG}+\mathrm{HP}$ diet resulted in lower faecal score and $\mathrm{pH}$ compared with other diets. Also faecal volume was smaller with the PM + WG diet compared with the other

Table 1. Nutrient intake, coefficients of apparent total tract digestibility, metabolisable energy and faecal traits of French bulldogs fed experimental diets with different protein sources

(Mean values and pooled standard errors; $n 8$ dogs per diet)

\begin{tabular}{|c|c|c|c|c|c|c|c|}
\hline \multirow[b]{2}{*}{ Item } & \multicolumn{4}{|c|}{ Diet } & \multirow[b]{2}{*}{ SEM } & \multirow[b]{2}{*}{ CV $(\%)$} & \multirow[b]{2}{*}{$P$} \\
\hline & PM & WG & $P M+W G$ & $P M+W G+H P$ & & & \\
\hline Body weight (kg) & $11 \cdot 4$ & 11.5 & $11 \cdot 3$ & 11.5 & & & \\
\hline \multicolumn{8}{|l|}{ Nutrient intake ( $\mathrm{g} / \mathrm{kg}$ body weight per $\mathrm{d})$} \\
\hline Natural matter & $16 \cdot 93$ & $17 \cdot 84$ & $18 \cdot 10$ & $19 \cdot 39$ & 0.76 & 22.91 & 0.2234 \\
\hline DM & 15.86 & 16.47 & 16.93 & 17.97 & 0.71 & 22.85 & 0.3127 \\
\hline Organic matter & 14.98 & $15 \cdot 63$ & $16 \cdot 16$ & $17 \cdot 12$ & 0.68 & $22 \cdot 91$ & 0.2652 \\
\hline Ash & 0.88 & 0.83 & 0.77 & 0.85 & 0.04 & $22 \cdot 86$ & 0.2756 \\
\hline Crude protein & 3.48 & $4 \cdot 17$ & 3.95 & 3.96 & 0.17 & 23.54 & 0.0923 \\
\hline Fat & 2.63 & 2.65 & 2.93 & $3 \cdot 10$ & 0.12 & 23.46 & 0.0627 \\
\hline $\mathrm{N}$-free extract & 8.63 & 8.29 & 8.90 & 9.56 & 0.38 & 22.95 & 0.2133 \\
\hline Crude energy (kcal/kg body weight per $\mathrm{d})^{*}$ & 72.86 & $76 \cdot 37$ & 77.07 & 82.95 & 3.28 & 22.85 & 0.2923 \\
\hline \multicolumn{8}{|l|}{ Apparent total tract digestibility (\%) } \\
\hline DM & $85 \cdot 22^{\mathrm{b}, \mathrm{c}}$ & $87 \cdot 35^{a, b}$ & $88 \cdot 77^{\mathrm{a}}$ & $86 \cdot 16^{\mathrm{b}}$ & 0.37 & 2.31 & 0.0234 \\
\hline Organic matter & $88.08^{\mathrm{b}, \mathrm{c}}$ & $89.61^{a}$ & $90 \cdot 44^{a, b}$ & $88 \cdot 28^{b}$ & 0.31 & 1.89 & 0.0237 \\
\hline Ash & 36.84 & 44.64 & 42.99 & 43.08 & 1.51 & 19.42 & 0.2791 \\
\hline Crude protein & $83.98^{\mathrm{b}}$ & $88.08^{\mathrm{a}}$ & $88.53^{\mathrm{a}}$ & $83.62^{\mathrm{b}}$ & 0.54 & 3.37 & 0.0001 \\
\hline Fat & $96 \cdot 75$ & $96 \cdot 47$ & $96 \cdot 92$ & $96 \cdot 56$ & 0.13 & 0.71 & 0.1600 \\
\hline $\mathrm{N}$-free extract & 91.71 & 92.09 & $93 \cdot 28$ & 91.78 & 0.27 & 1.61 & 0.1706 \\
\hline Crude energy & 88.31 & 89.58 & $90 \cdot 19$ & 89.70 & 0.47 & 2.84 & 0.5671 \\
\hline \multicolumn{8}{|l|}{ Faecal traits } \\
\hline Faecal pH & $6 \cdot 37^{a}$ & $6 \cdot 39^{a}$ & $6.44^{\mathrm{a}}$ & $6 \cdot 14^{\mathrm{b}}$ & 0.05 & 4.21 & 0.0190 \\
\hline Faecal score & $4 \cdot 34^{\mathrm{a}}$ & $4.46^{\mathrm{a}}$ & $4 \cdot 38^{\mathrm{a}}$ & $3.98^{b}$ & 0.07 & 9.06 & 0.0064 \\
\hline \multicolumn{8}{|l|}{ Faeces } \\
\hline $\mathrm{g}$ faeces/d (as fed) & $77 \cdot 68$ & 69.63 & 67.48 & $85 \cdot 88$ & $3 \cdot 16$ & 22.55 & 0.2158 \\
\hline $\mathrm{g}$ faeces/d (DM basis) & 82.96 & 74.38 & 74.24 & 91.49 & 0.94 & 20.94 & 0.0664 \\
\hline $\mathrm{g}$ faeces $/ 100 \mathrm{~g}$ food (as fed) & 42.34 & 35.60 & 35.44 & $40 \cdot 04$ & 1.18 & $16 \cdot 60$ & 0.1103 \\
\hline $\mathrm{g}$ faeces $/ 100 \mathrm{~g}$ food (DM basis) & $13 \cdot 84^{\mathrm{a}, \mathrm{b}}$ & $11 \cdot 68^{\mathrm{b}, \mathrm{c}}$ & $10 \cdot 97^{\mathrm{C}}$ & $12 \cdot 80^{\mathrm{b}}$ & 0.35 & $15 \cdot 22$ & 0.0206 \\
\hline
\end{tabular}

PM, poultry meal; WG, wheat gluten; HP, hydrolysed protein.

a,b,c Mean values within a row with unlike superscript letters were significantly different $(P<0.05$; Tukey's test).

* To convert kcal to $\mathrm{kJ}$, multiply by 4.184 . 
Table 2. Fermentation products: lactic acid, faecal ammonia, SCFA, branched-chain fatty acids (BCFA) and biogenic amines of French bulldogs fed experimental diets with different protein sources

(Mean values and pooled standard errors; $n 8$ dogs per diet)

\begin{tabular}{|c|c|c|c|c|c|c|c|}
\hline \multirow[b]{2}{*}{ Item } & \multicolumn{4}{|c|}{ Diet } & \multirow[b]{2}{*}{ SEM } & \multirow[b]{2}{*}{ CV (\%) } & \multirow[b]{2}{*}{$P$} \\
\hline & PM & WG & $P M+W G$ & $P M+W G+H P$ & & & \\
\hline Lactic acid (mmol/kg faecal DM) & $11 \cdot 38$ & 11.65 & $16 \cdot 59$ & $12 \cdot 82$ & $1 \cdot 14$ & 47.06 & 0.2372 \\
\hline Faecal ammonia (mmol/kg faecal DM) & 207.05 & $167 \cdot 80$ & 174.65 & 194.24 & 6.95 & $20 \cdot 19$ & 0.1078 \\
\hline \multicolumn{8}{|l|}{ SCFA (mmol/kg faecal DM) } \\
\hline Acetic & 92.47 & 97.73 & 101.9 & 96.97 & 4.05 & 22.43 & 0.9088 \\
\hline Propionic & 65.53 & 65.37 & 60.51 & $73 \cdot 15$ & 2.98 & $24 \cdot 27$ & 0.2502 \\
\hline Butyric & 3.56 & $3 \cdot 17$ & 2.91 & $3 \cdot 31$ & 0.21 & 34.52 & 0.2952 \\
\hline Total SCFA & $141 \cdot 37$ & $167 \cdot 82$ & $165 \cdot 33$ & $151 \cdot 75$ & $6 \cdot 56$ & $21 \cdot 21$ & 0.8318 \\
\hline \multicolumn{8}{|l|}{ BCFA (mmol/kg faecal DM) } \\
\hline Valeric & 0.68 & 0.62 & 0 & 0.75 & - & - & - \\
\hline Iso-valeric & 4.93 & 4.46 & $4 \cdot 36$ & 4.45 & 0.28 & 32.77 & 0.5805 \\
\hline Iso-butyric & 21.43 & $20 \cdot 73$ & 21.88 & $20 \cdot 65$ & 1.09 & $27 \cdot 84$ & 0.9896 \\
\hline Total BCFA & 23.15 & 26.78 & 22.96 & $22 \cdot 24$ & $1 \cdot 22$ & 25.50 & 0.9715 \\
\hline \multicolumn{8}{|c|}{ Biogenic amines (mg/100 $\mathrm{g}$ faecal natural matter) } \\
\hline Tiramine & 1.14 & 1.43 & 1.64 & 1.19 & 0.13 & $53 \cdot 19$ & 0.6454 \\
\hline Putrescine & $6 \cdot 28$ & 4.71 & $6 \cdot 79$ & 8.50 & 0.40 & $32 \cdot 22$ & 0.0960 \\
\hline Cadaverine & 0.75 & 0.90 & 0.77 & 1.00 & 0.10 & 61.46 & 0.7458 \\
\hline Spermidine & $2 \cdot 67$ & $2 \cdot 28$ & 2.95 & 2.60 & 0.14 & $28 \cdot 24$ & 0.2182 \\
\hline Feniletilamine & 0.23 & 0.00 & 0.48 & 1.35 & - & - & - \\
\hline Triptamine & 0.23 & 0.22 & 0.20 & 0.21 & 0.02 & 53.40 & 0.9235 \\
\hline Total amines & 11.30 & 9.54 & $12 \cdot 83$ & 14.85 & 0.79 & 32.79 & 0.9758 \\
\hline
\end{tabular}

PM, poultry meal; WG, wheat gluten; HP, hydrolysed protein.

diets ( $\mathrm{g}$ faeces $/ 100 \mathrm{~g}$ food on a DM basis). However, faecal fermentation metabolites did not differ among diets (Table 2).

\section{Discussion}

The crude protein CTTAD of the four experimental diets were high (Table 1), indicating good utilisation of the protein sources evaluated in the study. However, higher CTTAD were observed in the diets formulated with higher proportions of WG (WG and $\mathrm{PM}+$ WG diets). Stool production was greatest in the PM treatment, having a possible relationship with the low CTTAD of the protein, besides the other nutrients. Nery et al. ${ }^{(2)}$ evaluated diets formulated with PM and WG, together (WPMP) and separated and in different concentrations (WGLP: inclusion of $22 \%$ dietary protein; WGHP: inclusion of $39 \%$ dietary protein; WPMP: $29 \%$ dietary protein). These authors found higher coefficients of apparent digestibility of protein in WGLP $(86.6 \%$ ), in WPMP $(91.4 \%)$ and WPMP (86.2\%) comparing with only PM $(82.2 \%)$ diets. In the present study, the WG-based diet was formulated with $21 \%$ protein content and $13 \%$ of the total protein on a DM basis came from gluten. The results of protein digestibility for the WG $(88.08 \%)$ and $\mathrm{PM}+\mathrm{WG}$ $(88.5 \%)$ diets were similar or even better compared with the study cited. Partially, these best results may be related to the quality of the ingredients used in food formulation. However, the lower apparent digestibility coefficients of the PM + WG + HP diet, which were not expected, could be explained by lower starch gelatinisation $(77.7 \%)$. The influence of starch gelatinisation on improving protein digestibility has been studied by Loureiro $e t$ al. ${ }^{(24)}$

Some authors ${ }^{(25,26)}$ have reported that the ideal faecal score and $\mathrm{pH}$ values are expected with higher-quality protein at lower concentrations. This results in a reduction of colonic fermentation similar to that observed in the present study. Faecal scores did not differ among PM, WG and PM + WG treatments, but were similar to previous research with several breeds and sizes of $\operatorname{dogs}{ }^{(6)}$. This previous study found a high water content in the faeces of dogs fed with PM and lower moisture in the faeces of dogs fed diets containing WG. The low-protein fermentation in the present study is probably related to the lower flow of undigested proteins in the large intestine, due to the low protein content in the diets and the high digestibility of the same ones.

The study presented some limitations related to the lack of information in the literature about digestibility in brachycephalic dogs, and the use of WG in pet food as a protein source. These limitations restricted the discussion and references in the study. Also, the inclusion of a non-brachycephalic breed as a control in the study might have demonstrated differences between the breeds in this paper.

\section{Conclusion}

The WG used as the sole source of protein or in combination with PM increased protein digestibility. However, this effect was not able to alter the fermentation parameters measured.

\section{Acknowledgements}

The first author (M. I. G. U.) acknowledges the scholarship granted by CAPES (Brazilian Federal Agency for Support and Evaluation of Graduate Education).

Grandfood Ind Com LTDA provided the animals, raw materials and facilities used in this study. Grandfood Ind Com LTDA played no role in the study design, sample collection, data analysis and interpretation, and in the decision to submit the manuscript for publication. 
M. I. G. U. was responsible for planning the study, conducting the analysis, and writing and editing the manuscript. L. F. O. M. and D. F. S. were responsible for planning the study and manufacturing the diets. M. M., K. M. S. and M. C. E. were responsible for compiling the data and reviewing the manuscript. J. C. C. B. was responsible for data analysis. M. A. B., C. F. F. P. and L. F. A. were responsible for planning the study and composing and reviewing the manuscript.

\section{References}

1. Hand MS, Thatcher CD, Remirllard RL, et al. (2010) Small Animal Clinical Nutrition, 5th ed., p. 1314. Topeka, KS: Mark Morris Institute.

2. Nery J, Biourge V, Tournier C, et al. (2010) Influence of dietary protein content and source on fecal quality, electrolyte concentrations, and osmolarity, and digestibility in dogs differing in body size. J Anim Sci 88, 159-169.

3. Blachier F, Mariotti F, Huneau JF, et al. (2007) Effects of amino acid-derived luminal metabolites on the colonic epithelium and physiopathological consequences. Amino Acids 33, 547-562.

4. Boye J, Wijesinha-Bettoni R \& Burlingame B (2012) Protein quality evaluation twenty years after the introduction of the protein digestibility corrected amino acid score method. Br J Nutr 108, 183-211.

5. Kuzmuk KN, Swanson KS, Tappenden K, et al. (2005) Diet and age affect intestinal morphology and large bowel fermentative end-product concentrations in senior and young adult dogs. J Nutr 135, 1940-1945.

6. Nery J, Goudez R, Biourge V, et al. (2012) Influence of dietary protein content and source on colonic fermentative activity in dogs differing in body size and digestive tolerance. J Anim Sci 90, 2570-2580.

7. Zentek J, Marquart B, Pietrzak T, et al. (2003) Dietary effects on bifidobacteria and Clostridium perfringens in the canine intestinal tract. J Anim Pbysiol Anim Nutr (Berl) 87, 397-407.

8. Roudebush P, Davenport DJ \& Remillard RL (2010) Flatulence. In Small Animal Clinical Nutrition, 5th ed., pp. 1127-1133 [MS Hand, CD Thatcher, RL Remirllard, P Roudebush and BJ Novotni, editors]. Topeka, KS: Mark Morris Institute.

9. Cave N (2013) Gastrointestinal gas: eructation, borborygmus and flatulence. In Canine and Feline Gastroenterology, 1st ed., p. 124 [R Washabau and MJ Day, editors]. St Louis, MI: Elsevier Saunders.

10. Zentek J (1995) Influence of diet composition on the microbial activity in the gastro-intestinal tract of dogs. II. Effects on the microflora in the ileum chyme. J Anim Physiol Anim Nutr (Berl) 74, 53-61.

11. Laflamme D (1997) Development and validation of a body condition score system for dogs. Canine Pract 22, 10-15.

12. National Research Council (2006) Nutrient Requirements of Dogs and Cats. Washington, DC: National Academies Press.

13. Sá FC, Vasconcellos RS, Brunetto MA, et al. (2013) Enzyme use in kibble diets formulated with wheat bran for dogs: effects on processing and digestibility. J Anim Physiol Anim Nutr 97, 51-59.

14. Association of American Feed Control Officials (AAFCO) (2004) Official Publication. Oxford, IN: AAFCO.

15. Carciofi AC, Takakura FS, De-Oliveira LD, et al. (2008) Effects of six carbohydrate sources on dog diet digestibility and post-prandial glucose and insulin response. J Anim Physiol Anim Nutr 92, 326-336.

16. Pond WG, Church DC \& Pond KR (editors) (1995) Basic Animal Nutrition and Feeding, 4th ed. Chichester: John Wiley and Sons.

17. Association of Official Analytical Chemists (AOAC) (1995) Official and Tentative Methods of Analysis, 16th ed. Arlington, VA: AOAC International.

18. Walter M, Silva LP \& Perdomo DMX (2005) Biological response of rats to resistant starch. Rev Inst Adolfo Lutz 64, 252-257.

19. Pryce JDA (1969) Modification of the Barker-Summerson method for the determination of lactic acid. Analist 94, 1121-1151.

20. Erwin ES, Marco GJ \& Emery EM (1961) Volatile fatty acid analyses of blood and rumen fluid by gas chromatography. J Dairy Sci 44, 1768-1771.

21. Vale SR \& Gloria MB (1997) Determination of biogenic amines in cheese. J AOAC Int 80, 1006-1012.

22. Vieira PF (1980) Efeito do formaldeído na proteção de proteinas e lipídios em racoees para ruminantes (Effect of Formaldehyde on the Protection of Proteins and Lipids in Ruminant Diets). Viçosa: Universidade Federal de Viçosa.

23. SAS Institute Inc. (2004) SAS Statistics. Cary, NC: SAS Institute Inc.

24. Loureiro BA, Roberti FFO, Pacheco PDG, et al. (2014) Starch gelatinization degree and nutrient digestibility of extruded diets for dogs. In Proceedings of the Congress of the European Society of Veterinary and Comparative Nutrition, 18th ed., p. 43. Utrecht, the Netherlands.

25. Weber MP, Hernot D, Nguyen PG, et al. (2004) Effect of size on electrolyte apparent absorption rates and fermentative activity in dogs. J Anim Physiol Anim Nutr (Berl) 88, 356-365.

26. Hernot DC, Biourge VC, Martin LJ, et al. (2005) Relationship between total transit time and faecal quality in adult dogs differing in body size. J Anim Pbysiol Anim Nutr (Berl) 89, 189-193. 